\title{
Impact of smartphones on the achievement of sepak takraw learners
}

\author{
I Ketut Semarayasa ${ }^{1}$, Soegiyanto KS ${ }^{2}$, Setya Rahayu ${ }^{3}$, Taufiq Hidayah ${ }^{4}$ \\ 1,2,3,4 Universitas Negeri Semarang, Indonesia \\ ${ }^{1}$ Corresponding email: semarayasaiketut@gmail.com
}

\begin{abstract}
This paper aims at explaining impact of smartphones on the achievement of sepak takraw learners. The study used an ethnographic research design. The participants of the study were four learners of sepak takraw (ages 12 to 15). The data were collected by administering an in-depth interview and a non-participant observation. The analysis of data showed that the use of smartphones seemed to deteriorate the achievement of the sepak takraw learners. The excessive use of smartphones seemed to cause disruptive training sessions, lack of social interactions, lack of self-practice, and decrease physical health. This study indicated that smartphones might contribute negative impacts to its users. The study thus suggests that teachers/coaches should educate their young people to use smartphones wisely and effectively.
\end{abstract}

Keywords: smartphone, sepak takraw, achievement

\section{Introduction}

In the digital era, smartphones have been widely used by many people, including teenagers. Through the advancement of technology, smartphones are not only used as a means of communication but also as a medium of entertainment (Wang, Xiang, \& Fesenmaier, 2014; Wenyu, 2016). There are various media social applications such as Facebook, Instagram, Path, Twitter, YouTube, WhatsApp, LINE, and many others are readily installed in smartphones. Besides, there are also applications for video makers and pictures editors that can be used by smartphones users freely. The existence of video cameras and other entertainment tools such as MP4 players or movie applications also could fulfill the entertainment needs of the young people. Thus, it is natural to observe that the majority of teenagers owned smartphones and utilize smartphones in their everyday life.

Research demonstrating the use of smartphones among teenagers are relatively flourishing, particularly in educational contexts. Alfawareh \& Jusoh (2017) for example, conducted a study on the use of smartphones in a higher education. Their findings reveal that students utilized smartphones as a means of knowledge sharing. On the contrary, $\mathrm{Ng}$, Hassan, Nor, \& Malek (2017) demonstrated that university students tended to use smartphone for pleasure, not for learning. Accordingly, the study conducted by them indicated that the more students utilized their smartphone, the lower their academic achievement was. Similar to $\mathrm{Ng}$, Hassan, Nor, \& Malek (2017), Nwachukwu \& Onyenankeya (2018) also found out that college students used smartphones more for social activities than academic ones.

The use of smartphones is indeed observable in the educational contexts. However, few researchers have addressed how leaners use their smartphone in sport education context. In fact, smartphone is also widely used by learners in this area of investigation (Semarayasa, 2016). The present study attempted to fill this gap by exploring the use of smartphones by sepak takraw learners. This paper is organized as follows. Section 2 presents the research methodology used in the present study. Section 3 provides the research findings and discussions. Section 4 presents the conclusion of the study.

\section{Method}

The present study is a part of a larger study aiming to investigate the development of sepak takraw in Indonesian context viewed from a socio-cultural perspective. This study was conducted in one of Junior High Schools in Bangli Regency, Bali Province, Indonesia. The study used an ethnographic research design. This research design was applied as it could help the researchers to observe, collect, and analyze data in a natural context (Crang \& Cook, 2007). Besides, this research design also provided a room for the researchers to study people's behavior in a naturally occurring setting with the focus on the cultural interpretation of behaviors (Gay, Mills, \& Airasian, 2011). The participants of the study were four learners of sepak takraw (ages 12 to 15). They were selected by following a purposive sampling technique. There were 
three criteria for selecting the participants: they joined sepak takraw club in the context of the study, they were 12 to 15 years old, and they owned and used a smartphone (mobile phones using any of the following operating system: Apple iOs, Android, or RIM).

Data were collected by administering a non-participant observation and an in-depth interview. The procedures for collecting data were: providing verbal consent to the participants, interviewing the participants informally on a scheduled time and observing the daily activities of the participants. The data were analyzed by following some procedures: transcribing the interview, coding the interview, comparing the results of the interview and observation note, determining emergent themes, and drawing conclusions. In order to ensure the trustworthiness of the results, member check and peer debriefing were applied. With regard to member check, the researchers let the findings and their interpretations of the findings to be confirmed by the participants. In relation to peer debriefing, the researchers met at a scheduled time to code and interpret data.

\section{Results and Discussion}

The data analysis reveals that the use of smartphones among sepak takraw learners affect their achievement, in which their performance in sepak takraw tended to be low. This was caused by some reasons: disruptive training sessions, lack of social interactions, lack of self-practice, and decrease physical health. Each of these emergent themes is discussed in the following sessions.

\section{Disruptive training sessions}

The use of smartphone seemed to distract the participants during their training sessions. The participants were observed that they lost their focus when they practiced sepak takraw skills (kicks, serves, and spike). The participants paused the practiced sessions many times to check their smartphones. Surprisingly, they used their smartphones to take pictures, to make a vlog, and to video call with their virtual friends. Instead of performing sepak takraw skills to improve their achievement, the participants only took actions for the sake of their media socials.

From the interview, it was found out that the participants could not stop their feelings to always check their smartphones. They were curious about "likes" and "comments" that they had on the pictures/photos that they had uploaded in their media socials (Facebook, Instagram, and Path). These made them distract their focus and concentration during the training. Thus, the training could not run effectively.

"I always want to check my smartphones. I feel incomplete when I do not check my media social's notifications. Even, I feel guilty if I did not reply to comments on my media socials". (Participant 2,4)

"I like posting my sepak takraw skills on my Instagram. I usually performed live IG story. That's why I always bring my smartphone with me when I practiced sepak takraw". (Participant 3)

"When I practice, I usually bring my smartphones. I always take some photos and directly uploaded to my Facebook and Path account". (Participant 1)

These research findings were in line with Kibona (2015), Rabiu, Muhammed, Umaru, \& Ahmed (2016) and Sundari (2015). They found out that the frequent use of smartphones interferes with students' learning, focus, concentration, and attention toward the learning subjects. As a result, their performances in learning were low.

\section{Lack of social interaction}

Data analysis might indicate that there was little interaction between the participants and their peers as well as their teachers/coaches. During the break sessions, the participants spent more time on their smartphone's screen than their peers or teachers/coaches. Thus, there was little face to face interaction among the participants. Additionally, the review stage after the training sessions was not effectively done. This was because the participants seemed to neglect the feedback's session provided by their teachers/coaches. When the teacher/coaches gave feedbacks to them, they still tried to check their smartphones secretly.

From the interview, the participants acknowledged that they prefer to chat with their virtual friends than their peers. During break sessions, they used their time the most to check their media socials.

"When I have a time break, I take my smartphone and check my Instagram account". (Participant 1,2) 
"During break session, I chat with my friends in my Whatsapp messenger and LINE messenger". (Participant 3,4)

These actions had affected the achievement of the sepak takraw learners. The participants seemed to ignore the importance of reviewing sessions and feedback given sessions from the coaches. Whereas, these sessions are beneficial to improve their sepak takraw skills performances (Minoo, Nasser, \& Misagh, 2014; Sunaryadi, 2016).

\section{Lack of self-practices}

The excessive use of smartphones among sepak takraw learners led to having a lack of self-practices. Before the training sessions begin, the participants played online video games or watched YouTube channel on their smartphones. They rarely did self-practices by practicing sepak takraw skills independently before the teachers/coaches came. Even, they kept on playing online video games even though their teachers/coaches were present.

The result of the interview also indicated that the participants could not avoid themselves to play online video games on their smartphones.

"I played online video games every day. When I play, I almost forget the time". (Participant 2,3)

"I like watching Film through VIU applications and YouTube channels. I do not need to go to the movie for watching my favorite films". (Participant 1,4)

The smartphones usage among the participants of the study made them unmotivated to do self-practices. They preferred to use their time more on their smartphone's screen than to practice sepak takraw skills independently. When this action continuously occurs, this can cause low achievement of the learners as selfpractices play an important role to increase the learners' performances and achievements in sports (Ford, Ward, Hodges, \& Williams, 2009).

\section{Lack of physical health}

The frequent use of smartphones might also decrease the participants' physical health. It was observed that the participants got tired easily and experienced pain in the wrists, back or neck of the participants. From the result of the interview, it is revealed that the participants used their smartphones until midnight for entertainment and social purposes.
" I bring my smartphone wherever I go, even to my bed. I chat with my virtual friends, post pictures, edit pictures, and write unique captions for my media socials. Then, I spent most of my time to see my friends' media social such as Instagram or Facebook. I want to know what's going on with him or her. Even, I stalk my exgirlfriend Instagram's account. Besides, I also follow IG account of my idol" (Participant 1,2).

"I spent my time the most to play online video games, such as Mobile Legends. I feel anxious if I miss playing this game. I play the game until midnight on my bed. I also like watching YouTube channels on my smartphones". (Participant 3,4).

These research findings were similar to the study conducted by Arefin (2017), who found out that the use of smartphones might cause daily life disturbance such as hard to concentrate, feeling tired and lacking adequate sleep, cannot stop using smartphones, and constantly checking smartphones.

\section{Conclusion}

This study concludes that the excessive use of smartphone make the learners addicted to it and might cause the low achievement for the sepak takraw learners. To avoid the negative impact of the smartphone usage, it is suggested for teachers/coaches to provide rules on using smartphones for teenagers. By so doing, the learners can minimize the use of their time on their smartphone and provide ample of time for more real activities, such as practicing sepak takraw skills with their friends, doing selfpractice more regularly, and focusing their concentration during the training sessions.

\section{References}

Alfawareh, H.M. \& Jusoh, S. (2017). The use and effects of smartphones in higher education. International Journal of Interactive Mobile Technologies (iJIM), 11(6), 103-111.

Arefin, M.S.,et.al. (2017). Impact of smartphone addiction on academic performance of Business students: A case study. Independent Journal of Management \& Production, 8 (3), 955-975.

Crang, M. \& Cook, I. Doing Ethnographies. London: Sage publications, 2007. 
Ford, P.R., Ward, P., Hodges, N.J., \& Williams, A.M. (2009). The role of deliberate practice and play in career progression in sport: the early engagement hyphothesis. High Ability Studies, 20 (1), 65-75.

Gay, I. R., Mills, G.E., \& Airasian, P.W. Educational Research. Competencies for Analysis and Application. Boston: Pearson, 2011.

Kibona, L. (2015). Smartphones' effect on academic performance of higher learning students. A case of Ruaha Catholic University-Iringa, Tanzania. Journal of Multidisciplinary Engineering, Science and Technology (JMEST), 2 (4), 777-784.

Minnoo, D. Nasser, B., \& Misagh, H. (2014). The effect of coach feedbacks behaviours on intrinsic motivation and satisfaction in elite athletes of Golestan Province. European Journal of Experimental Biology, 4(1), 523-526.

Ng, S.F., Hassan, N.S.I.C., Nor, N.H.M., \& Malek, N.A.A. (2017). The relationship between smartphone use and academic performance: A case of students in Malaysian Tertiary Institution. Malaysian Online Journal of Educational Technology, 5(4), 58-70.

Nwachukwu, C. \& Onyenankeya, K. (2018). Use of smartphones among college students in Nigeria:Revelations and Reflections. Journal of Communication, 8(2), 171-182.
Rabiu, H., Muhammed, A.I., Umaru, Y., \& Ahmed, H.T. Impact of mobile phone usage on academic performance among secondary school students in Tarab, State Nigeria. European Scientific Journal, 12 (1), 466-479.

Semarayasa, I.K. (2016). Utilizing mobile phone video in teaching sepak takraw gunting spike. The Second International Seminar on Education Technology (ISET), 25 May 2016, 428-433.

Sunaryadi, Y. (2016). The role of augmented feedback on motor skill learning. Advances in Economics, Business and Management Research, 14, 271-275.

Sundari, T.T. (2015). Effects of mobile phone use on academic performance of college going young adults in India. International Journal of Applied Research, 1 (9), 898-905.

Wang, D., Xiang, Z., \& Fesenmaier, D.R. (2014). Smartphone use in everyday life and travel. Journal of Travel Research. Available http://jtr.sagepub.com/content/early/2014/ 05/16/004728751.

Wenyu, X. (2016). Rational use of smartphone in English learning. Advances in Social Science, Education and Humanities Research (ASSEHR), 75, 343-346. 